REPORTS OF MORPHOLOGY
Official Journal of the Scientific Society of Anatomists,
Histologists, Embryologists and Topographic Anatomists
of Ukraine
journal homepage: https://morphology-journal.com

\title{
Electron microscopic diagnostics of apoptosis processes under simulation conditions in the experiment of acute pyelonephritis and concomitant diabetes mellitus type I and II
}

Borysov S.O., Kostyev F.I., Borysov O.V., Molchanyuk N.I.

Odessa National Medical University, Department of Urology and Nephrology, Odessa, Ukraine

\section{ARTICLE INFO}

Received: 5 December, 2017

Accepted: 16 January, 2018

UDC: $616.61-002.16-092: 616.397-$ 008.64

\section{CORRESPONDING AUTHOR}

e-mail: borisov-urol@ukr.net Borysov S.O.
According to literature data, in the conditions of the balance of pro- and antiinflammatory factors, the development of the infectious-inflammatory process tends to progress and more severe with subsequent transformation into chronic inflammation with corresponding morphofunctional effects. Under such critical conditions, an apoptosis is likely to play a crucial protective role, which can eliminate the excessive accumulation of aggressive inflammatory effects and effectively eliminate them, which in the future prevents the probable transformation into a persistent form. The aim of the work was to study the features of the early dynamic processes of apoptosis in the tissues of the kidneys under simulation conditions in the experiment of acute pyelonephritis and concomitant diabetes mellitus type I and II. The purpose of the study was to study the feature sof the early dynamic processes of apoptosis in the tissues of the kidneys under simulation conditions in the experiment of acute pyelonephritis and concomitant type I and type II diabetes. The work was performed on 300 adult Wistar rats, which were divided into 4 groups. Fragments of animal's kidneys were studied and photographed in an electron microscope PEM-100-01. The results showed that after modeling in the animals of pyelonephritis in the nephrons there were no significant ultrastructural changes. The structure of the podocytes of the outer sheet was almost the same as the structure of the podocytes of the control material, and in some cells therewere signs of activation of their metabolic activity. In the structure of the podocytes of the inner leaf of the capsule, dystrophic changes of the internal membrane of the mitochondria were established. In kidney medulla, the structure of the glomerulus was more preserved than in the cortical. Pathological changes of the proximal and distal tubular podocytes, as well as interstitial tissue, are more pronounced than the renal glomeruli. Under themodeling of the common model of pyelonephritis and type 1 diabetes, more pronounced morphological changes occur: destructive changes in the endothelial cells of the glomerular capillaries, the homogenization of the structure of the basement membrane occurs and the mesangial tissueis significantlyenlarged. In nephrons and tubules of cortex, changes are manifested to a much greater extent than in the kidney medulla. When studying in clinical conditions the pathogenetic features of acute pyelonephritis in conditions of concomitant diabetes mellitus it is expedient to carry outelectron microscopic research with the aim of choosing the optimal corrective therapeutic effect and preventing the unfavorable course of infectious and inflammatory process and its transformation into persistent form. EM (electron-microscopic) studies arehighly informative in the study of pathological changes and early dynamic processes of apoptosis in renal tissues in the design of acute pyelonephritis and concomitant diabetes mellitus I and II in the experimental conditions. Keywords: modeling, pathogenesis, pyelonephritis, diabetes mellitus, electron microscopy, cortical and cerebralmatter, apoptosis.

\section{Introduction}

Current scientific evidence suggests the participation of apoptosis - programmable cell death (PCD) in the pathogenesis of a significant number of infectious and inflammatory processes that have an active course and a 
tendency to chronicity $[3,7,15,18]$. The foregoing allows to classify apoptosis as a universal general-pathological process of early development of numerous diseases and pre-nosological syndromes of infectious and inflammatory origin.

It has been established that apoptosis is capable of implementation both in structurally undamaged tissues and in the presence of signs of a pathological process in them. Apoptosis is considered as a natural and logical result of the implementation of receptor-mediated mechanisms of selfdestruction of the cell. At the same time it is emphasized that the adaptive role of PCD is absolutely obvious [3, 12, 17, 18].

Literary data testify that in the conditions of a violation of the balance of pro- and anti-inflammatory factors, the development of the infectious-inflammatory process is characterized by a tendency towards progression and a more severe course of inflammation and its transformation into chronic inflammation with severe morphofunctional consequences. It is suggested that under such critical conditions, an apoptosis that can eliminate the excessive accumulation of aggressive inflammatory effects, their effective elimination, which in the future will provide a more favorable course of the inflammatory process and prevent its transformation into a persistent form, plays a decisive protective role $[2,10,11,13,14]$. The data of many authors underlines the transience of the process of self-destruction of cells, for completing which is enough for several minutes or hours [1, 2, 4, 10, 16].

Based on the foregoing, the purpose of this work was to study the features of the early dynamic processes of apoptosis in the tissues of the kidneys in terms of simulation in the experiment of acute pyelonephritis and concomitant diabetes mellitus type I and II.

\section{Materials and methods}

The work was performed on 300 adult rats of the Vistar line, which were divided into 4 groups: group A - control (30 intact animals); group B (35 animals, which were modeled acute pyelonephritis); group C (50 animals with simulations of acute pyelonephritis and type I diabetes); group D (50 animals with simulations of acute pyelonephritis and type II diabetes mellitus).

For electron microscopy, the kidney fragments were fixed in $2.5 \%$ glutaraldehyde solution in phosphate buffer at a $\mathrm{pH}=7.4$, followed by fixation with $1 \%$ solution of osmic acid at the same $\mathrm{pH}$ of the buffer solution. The samples were then dewatered in alcohols of ascending concentration. The material was etched and its conclusion was carried out in a mixture of epoxy resins Araldite-Epon. Subsequently, ultrathin sections were contrasted with the Reynolds technique [15].

The research objects were studied and photographed in an electron microscope PEM-100-01, 148 electronic microphotographs were obtained and analyzed. The work is performed as a part of the group of electron microscopy of the laboratory of pathoanatomical and electron microscopic research.

\section{Results}

At the electron microscopy (EM) study of the kidney cortex of animals in the control group $(A)$, it was found that nephrons of the cortex have an electron-dense tissue of the Bowman capsule, under which on the basement membrane place epitheliocytes (podocytes) of the outer sheet of the capsule (OSC). These cells consist of a thin layer of flattened cells that also have an electron-dense cytoplasm and a nucleus $(\mathrm{N})$, which contains mainly chromatin in a condensed state. Especially it should be noted its boundary location, that is, there is a margin of chromatin. The organelles of these cells are small, are defined indistinctly. Alongside the cells of this layer are located with more electron-light cytoplasm and karyoplasm. In the cytoplasm, there are isolated mitochondria $(\mathrm{M})$, polysome (P), and granular endoplasmic mesh (GEM) tanks. Between the outer and inner leaves situated a cavity of the capsule (Fig. 1).

Podocytes of inner leaf occupies a large area and are located in the cavity; cytotrabecules contacting each other from different parts of the inner leaf. In the cytoplasm of the podocytes there is a lot of polysome, mitochondria, GEM elements, well-developed Golgi complex. The nucleus is predominantly circular with a convoluted karyolemma.

The glomerulus has a well-developed capillary mesh. Part of the capillaries of the body of the endothelial cells (EC) often overlap their lumen. The cells have large nuclei with invaginations and folds of karyolemma. Karyoplasm and cytoplasm electron-light. In the nucleus, there is a margin of chromatin. In the central zone chromatin is in a diffuse state. In the cytoplasm of the EC there are diffuse single mitochondria, Golgi complexes, polysomes and small foam

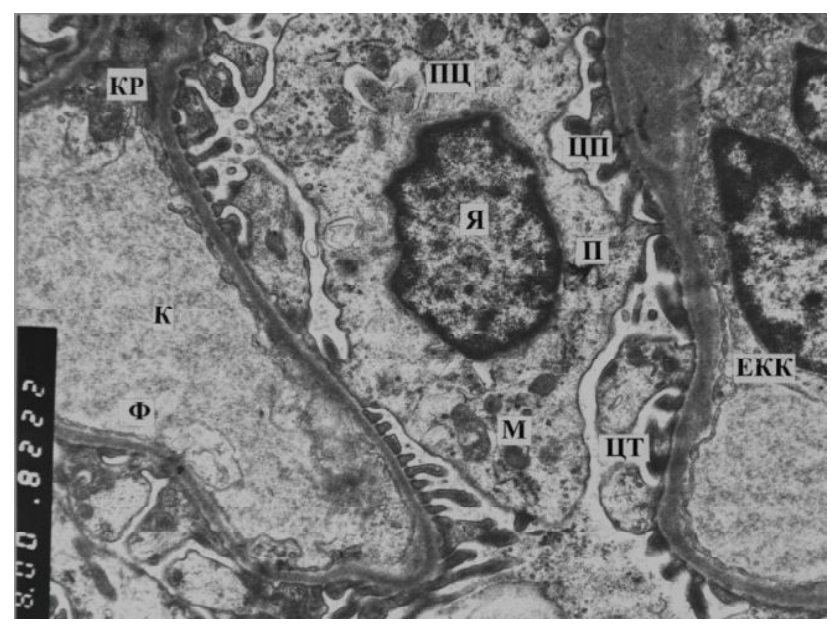

Fig. 1. Ultrasonography of the rat kidney cortex of the control group, a fragment of the capillaries and the podocyte in the normal state. EM x8000. Here and thereafter: KP - cortical substance, $\mathrm{K}$ - capillary, EKK - endothelial cell of the capillary, Ф - fenestrations, ЦТ - cytotrabecula, ЦП-cytopodes, ПЦ-podocyte, П- polysome, Я - nucleus, M - mitochondria, MP - renal medulla, EKK capillary endothelial cell, МЦ - mesangiocyte, E - erythrocyte, MP - renal medulla, ЗЛК - outer layer of the capsule, IT - interstitial tissue, B - vacuole, IT - interstitial tissue, ПК - proximal tubule, БM - basal membrane, KKC - glomerular capillary mesh. 
cytoplastic vesicles. In the lumen one can see red blood cells (E). Fenestra, located on the groomed areas of the EC, are well expressed. Proximal tubules (PT) are lined with podocytes of cuboid shape, which lie on the basement membrane. They have a basal strain and apical microvilli, which form a brush rim. In the cytoplasm of these cells there is a round nucleus and a large number of mitochondria, polysomes and single elements of the GEM.

With further EM studying of the kidney medulla of animals of the control group (A), it was discovered that the podocytes of the outer sheet adhere tightly to the basement membrane. Basically, these cells have a flattened form, a spindle-shaped core and a small cytoplasmic strip. In some podocytes, cytoplasmic spinal cord and karyoplasm are electron-light. In the nucleus of these cells, there is a margin of chromatin. Euchromatin, which occupies almost the entire area of the karyoplasma, is indistinguishable, fragmented, contained in small quantities. Polysomes, small round mitochondria are well defined in the cytoplasm. To the outer sheet, the large size of the podocytes of the inner sheet are closely adjacent to each other, the slit of the cavity is very narrow, in places its larger space is determined. They have a large nucleus with a convoluted karyolemma. The chromatin of the nuclei is in a diffuse state. The cytoplasm is saturated with narrow, small tubules of GEM, polysomes and a small number of mitochondria. To the basement membrane closely adhere to polypodia (Fig. 2).

The glomerulus has a winding basal membrane. EC of capillaries have large sizes, their phenesters are well defined. The cytoplasm has a regular set of organelles. In a number of capillaries, the cytoplasm is slightly electron-light, containing a reduced number of their intracellular organelles. In the cavity of the capsule, in addition to the podocyte, there are fragments of individual cytotrabecula. In the lumen of the capillaries place a fine-grained material. PT and distal tubules (DT) by ultrastructure do not differ from such in cortex.

Electron microscopically examined kidneys of animals of group B (simulation of acute pyelonephritis). In the study of kidney cortex, it was found that the podocytes of the outer sheet of the renal corpuscles were associated with signs of activation of protein-synthetic activity in the cytoplasm: an increased number of polysome increased in size, enlarged tubules of GEM, in profiles of which there was a fine-grained substance (Fig. 3). The cytoplasm of the podocytes of the inner leaf was somewhat compressed; part of the mitochondria was detected with complete destruction of the cristae. In the capillaries, the number of phenesters has been reduced, as well as marked breaks in the field. Occasionally there was a narrowed clearance in capillaries with cell fragments in it. In general, the structure of capillaries is close to such in control animals (Fig. 3).

The podocytes of the PC have reduced the number of mitochondria, and the existing mitochondria are closely adjacent to each other and have complete or partial destruction of cristae, which is possibly due to increased energy expenditure on intracellular processes. The nuclei

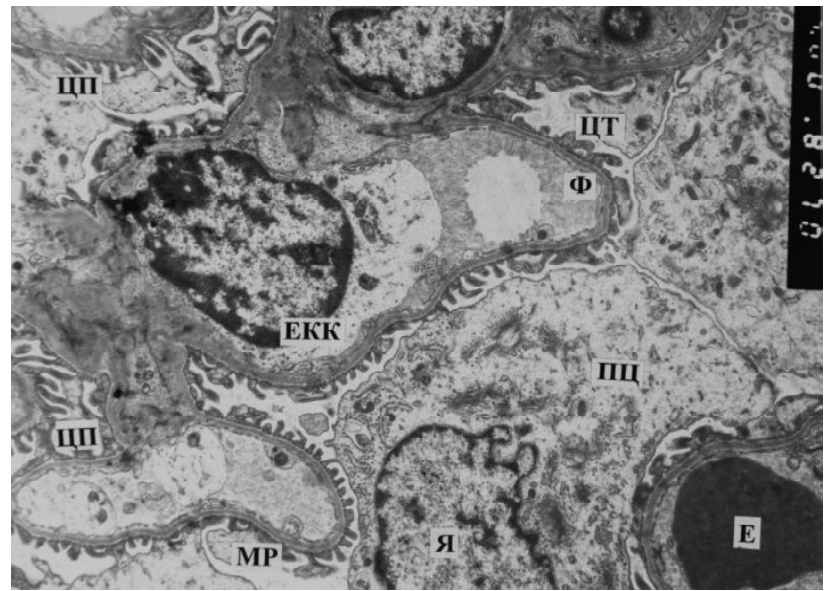

Fig. 2. Ultrastructure of the rat kidney medulla of the control group, a glomerular fragment with a normal ultrastructure. EM $\times 4000$.

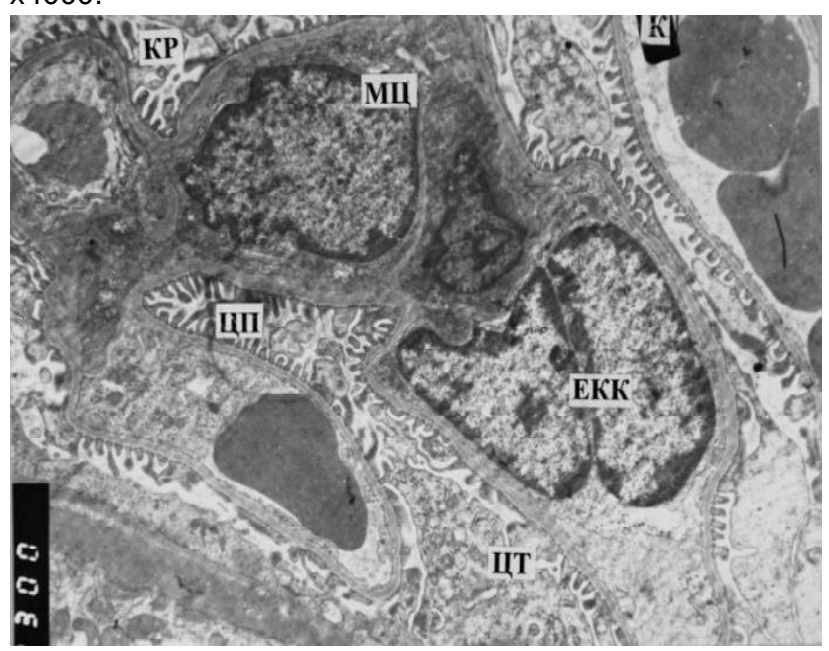

Fig. 3. Ultrastructure of rat kidney cortex after acute pyelonephritis modeling. A fragment of a glomerular capsule with signs of edema of the internal-mitochondrial matrix and destruction of mitochondria. EM x4000.

of these cells have an enlightened karyolemma, well-defined nuclear pores and a nucleolus located near the karyoplasm, indicating the activation of metabolic processes between the nucleus and the cytoplasm. In the cytoplasm, lysosomes and vacuoles also appear. On the basal surface there are shallow, rarely located basal folds.

In the electron microscopic study of medulla of group B animals, it was found that in the renal glomerulus the outer sheet under the basal membrane, consisting of flat podocytes, which contain large oval-shaped nuclei, is well defined. The chromatin of the nuclei is in diffuse state, the narrow rim under the karyolemma is the condensed chromatin. The cytoplasm of these cells is slightly enlightened, the organelles are somewhat sparse in the cytoplasm, compared with that in the control material. In a number of cells there are two nuclei.

The cytoplasm is full of organelles. The mitochondria with the destruction of crystal and the enlightened matrix 


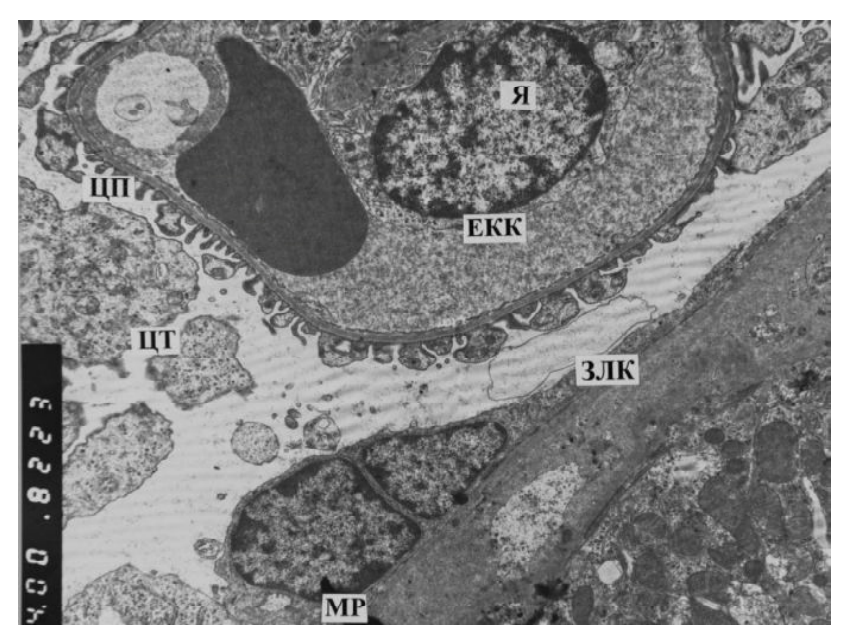

Fig. 4. Ultrastructure of the kidney medulla of the rat, model of acute pyelonephritis against the background of diabetes mellitus type I. Large cytotrebeculawith an increased number of organelles, in it mitochondrias with a sign of edema and destruction of christ. EM $\times 3000$.

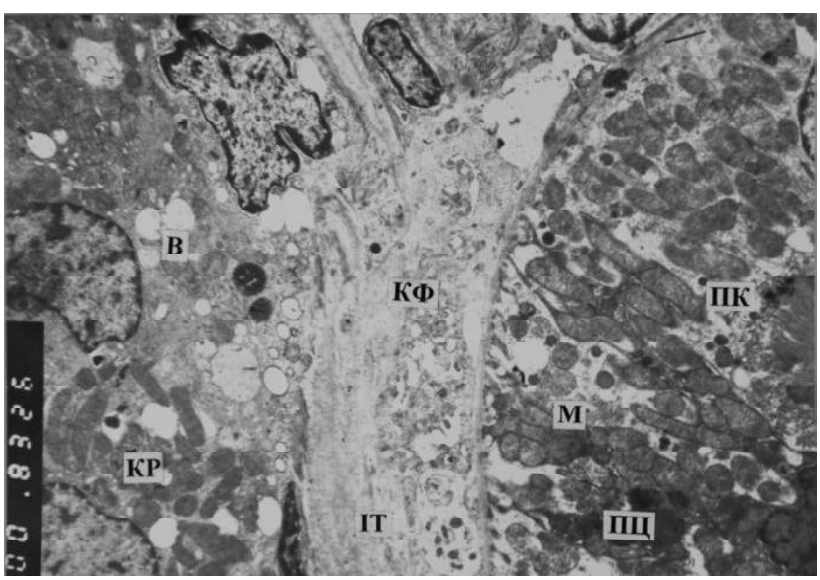

Fig. 5. Ultrasound of the rat kidney cortex after the simulation of acute pyelonephritis against the background of diabetes mellitus type I. The proximal tubule is suspected with electronically transparent cytoplasm and elements of destruction of some mitochondria's. EM x3000.

are determined, with a lot of polysome. A number of podocytes has spindle-shaped nuclei. The capillaries of the glomerulus, unlike the control material, have elevated electron-density content. EC with a large round nucleus and swollen mitochondria. Podocyte the inner leaf - large, especially their cytotrabecula. Separate cytotrabecula are located in the cleft area, along with the individual fragments of cells visible. Large bodies of podocyte act at a considerable distance to the space of the gap (Fig. 4). Sometimes cytotrabecula have the appearance of narrow strands, which extend over a large distance in the cavity of the capsule, in contact with other cytotrabecula on the opposite side of the glomerulus. Cytopedicules are sometimes thinned, in places, on the contrary, hypertrophic, that is, thickened containing a fragment of the cytoplasm.

It should be noted that in the renal corpuscles is a well- defined area of the cavity. It is more expanded than control.

A more preserved medulla glomeruli than the kidney cortex is found. PT and DT with the phenomena of organelle destruction, especially mitochondria with the formation of a large number of vacuoles, and the edema of the cytoplasmic matrix. Signs of minor hydroponic changes are also observed in the interstitial tissue.

Thus, the results of our study showed that after simulation of pyelonephritis in animals in kidney nephrons no significant ultrastructural changes are detected. The structure of the podocytes of the outer sheet is practically similar to the control material. At the same time, in some cells there are signs of activation of their metabolic activity. In the podocytes of the inner leaf of the capsule, dystrophic changes in the internal membrane of the mitochondria section are noted, which may indicate an increased energy need for cells and is an indication of the initial mechanism of apoptosis, according to modern data. When comparing the ultrastructure of the cortical and cerebrospinal fluid of the kidney, it is found that in the medulla the structure of the glomeruli is more preserved than in the kidney cortex.

Pathological changes in the podocytes of the PT and DT and in the interstitial tissue are more pronounced than in the renal glomeruli.

The EM-study of the cortex of group C animals (simulations of acute pyelonephritis and type I diabetes mellitus) made it possible to establish that in the renal glomerulus the podocytes of the outer sheet in places, according to the ultrastructure, do not differ from such control material, there was occasional discontinuity of their plasmolemma. The structure of the basement membrane in this area has a layered composition. Podocytes the inner leaf in its greater part with pronounced signs of edema and complete absence of organelles, that is, their hydropic degeneration is observed. These cells in their swollen bodies completely overlap the cavity of the capsule. A part of the same podocyte has a structure more preserved, but they are determined by the expansion of the elements of the GEM and swelling of the mitochondria (Fig. 5). Cytopedicules are sometimes elegant and elongated, but sometimes they are thickened, but they all have a cytoplasm of elevated electron density. A number of EC capillaries are also characterized by hydropic degeneration. In their lumen, there are single or multiple erythrocytes, they are aggregated or slag. Phenesters are poorly defined in them. Other capillaries have a normal structure or with the cellular desolation of organelles and signs of hypostasis of the cytoplasmic matrix. Some of the capillaries are deformed, the lumen is narrowed.

In a number of capillaries the body of large EC overlap their lumen, the structure of these cells without visible changes. Enlightenment of all capillaries of elevated electron density.

PT and DT with the phenomena of organelle destruction and swelling of the cytoplasmic matrix, sometimes there is no basal strain in them. Signs of hydroponic changes are 


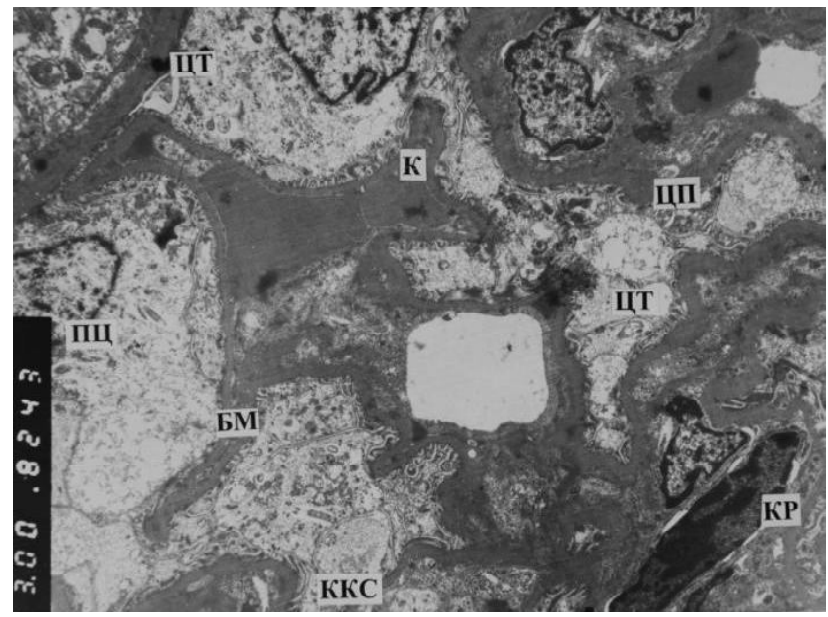

Fig. 6. Ultrasound of the rat kidney cortex after acute pyelonephritis modeling against the background of type II diabetes mellitus. Desolation of capillaries, hypertrophied podocytes in a state of destruction. EM x3000

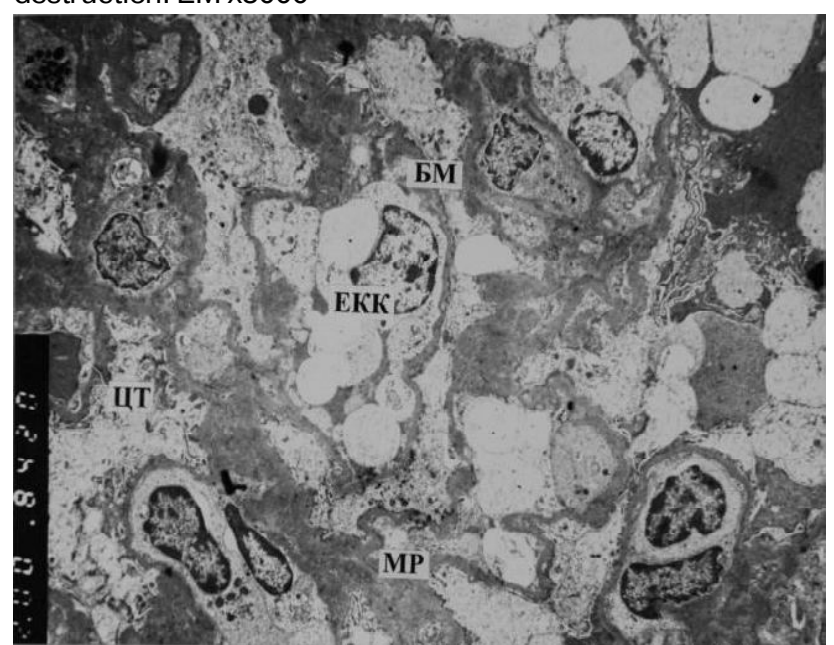

Fig. 7. Ultrastructure of the kidney medulla of the rat after the simulation of acute pyelonephritis against the background of type II diabetes mellitus. Focal narrowing of the capillaries, destructive changes in the cytoplasm of the endothelial cells of the capillaries in the podocytes glomerular capillary mesh. Homogenization of the basement membrane. EM x3000.

observed in the interstitial tissue.

Regarding the state of the medulla of the kidneys of the animals of the group C (model of AP and DM type I), the EM data indicate that the podocytes of the outer sheet are slightly flattened. Cell nuclei are hyperchromic. Single membrane structures are in a state of destruction. Capillaries are sometimes narrowed. Enlargement of most of the capillaries is densely filled with erythrocytes. Their EC have a slightly electron-transparent cytoplasm and there is a destruction of intracellular organelles, that is, there are pronounced deep hydrophilic changes. Other EC capillaries are more preserved, only destruction of mitochondria and expansion of GEM tanks is observed in them. A number of EC according to the structure does not differ from the EC of the capillaries of the control group. Most of the podocytes of the inner leaf are somewhat large in size. They are intimate contact with each other. However, some of them have signs of hydroponic changes. Intracellular structures in the state of destruction. Cytopedicules also have destructive changes, sometimes absent. The basal membrane of the glomerulus is homogenized. PT podocytes with enlightened cytoplasm and elements of destruction of organelles, especially mitochondria, and the location of a large number of vacuoles in it. Basal strain looks sparse. In DT in podocyte there is homogenization of mitochondria crust and the destruction of other organelles. A nucleus with an enlightened karyoplasm, in which there are osmiophil debris and flakelike material instead of chromosomes. In the interstitial tissue signs of edema of the main substance and cytoplasmic structures of EC of capillaries.

When comparing the ultrastructure of rat kidney nephrons after modeling of pyelonephritis and the common model of pyelonephritis and type I diabetes, it should be noted that the latter model shows more pronounced changes that are manifested by significant destructive changes in the EC of the glomerular capillaries, which lead to the complete desolation of most of the capillaries and before pronounced destructive changes in podocyte; in the homogenization of the structure of the basement membrane; expanded prolapse of mesangial tissue. The cavity of the capsule is completely absent. In podocyte, there are also signs of alteration of their ultrastructure. Podocytes of PT and DT, as well as elements of interstitial tissue with signs of deep destruction of their structures.

At the same time, we conducted the EM study of the cortical substance of the kidneys of the animals of group $D$ (modeling of AG and DM type II), in which it was found that the basement membrane of the capsule is dense, thickened in some places. The outer sheet podocytes are compacted, others with a larger area of the nucleus, irregular shape, part of the cells in a state of collapse, are sometimes absent. The cavity of the capsule is completely absent. Many of the podocytes of the inner leaf are enlarged in size, the cytoplasm of their light, edema. The cytoplasmic organelles of the podocytes and their processes are in a state of degradation of varying degrees. Some of these cells are completely devastated, detritus is determined instead of intracellular structures (Fig. 6). The glomerular capillaries are deformed, sometimes sharply narrowed or rescued, having a nodular shape. Enlargement of the capillaries is densely filled with erythrocytes. EC in many capillaries is absent or necrotized. A part of these cells has a round nucleus, its karyolemma with invaginations and folds, chromatin is practically destroyed.

In podocytes of PT there is considerable devastation of intracellular organelles. The cells reveal a nucleus with a normal structure, near which there is a significant amount of polysome, a small number of mitochondria, whose cristae are homogenized or are in a state of dystrophy.

In DC, the organelles of the central and apical part of the cytoplasm of the podocytes are more damaged. In interstitial 


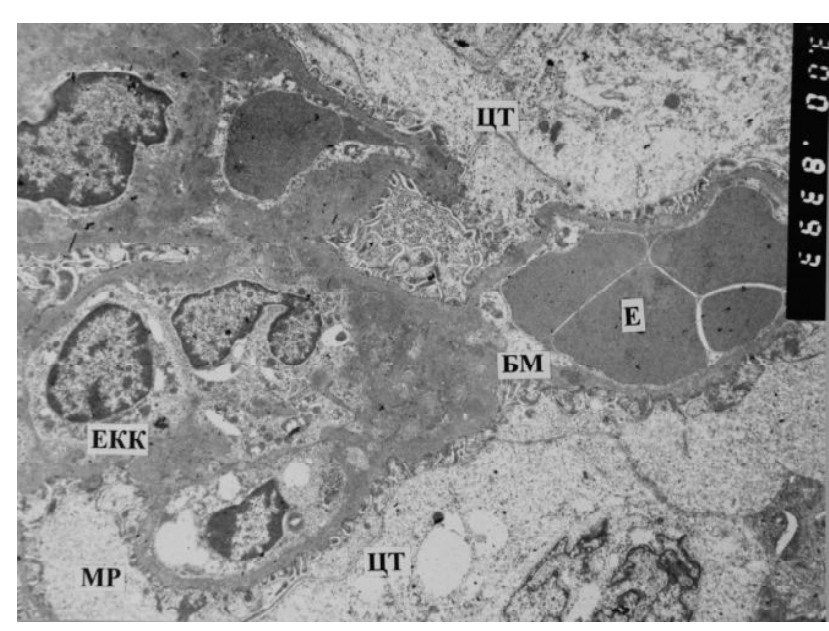

Fig. 8. Ultrastructure of the kidney medulla of the rat after the simulation of acute pyelonephritis against the background of type II diabetes mellitus. Signs of edema of endothelial cells and sludge of red blood cells in capillaries, hydrotheric changesand destruction of organelles of large cytotrabecular capsules. Reduction of part of cytopodes. EM x3000.

tissue there are elements of intracellular degeneration of EC capillaries and other cells with illumination of its basic substance.

A similar study of the medulla of the kidneys of animals of group D (model of AG and type II diabetes) has shown that polymorphic changes in EC capillaries are determined in the glomeruli. Part of the capillaries in its structure is close to normal. It is noted only the expansion of the elements of the WES and the cristae destruction of the mitochondria. Other EC with signs of varying degrees of destruction of cytoplasmic organelles. Enlightenment of capillaries is filled with homogeneous, with elevated electron-dense content. In the electron-dense lumen, there are isolated red blood cells. In the capillaries of a large caliber there is a glut of red blood cells in the lumen. Podocytes, their cytotrabecula and the cytopedicules of the inner leaf are mainly in the state of necrosis or severe degeneration of the cytoplasmic organelles, although in places there are cells with a virtually preserved structure(Fig. 7).

In podocytes of PT and DT, as well as in interstitial tissue, there are unidirectional ultrastructural changes, as in microstructures of the cortex, however, they are expressed in places to a lesser extent.

The EM differences between the model of pyelonephritis and concomitant diabetes type II from the model of pyelonephritis are: in this model, the capillaries are significantly narrowed, some narrowed, some of them formed nodes. The structure of the basement membranes is homogenized, thickened in the empty capillaries. EC in such capillaries in a state of destruction, their gap is densely filled with erythrocytes. Podocytes the outer sheet in a state of deep degeneration. Decide the inner leaf and cytotrabecula in the state of hydropic degeneration. Pedicle shortened, sometimes absent. In the PT there is a local destruction of organelles, individual mitochondria with cristae homogenization. Elements of interstitial tissue in the state of edema. The structure of the cortex is more damaged than the medulla (Fig. 8).

The PT has a lot of vacuoles in the apical area. In the DT there is a reduced number of mitochondria. In interstitial tissue there are elements of edema of the main substance. Structure of the medulla is more preserved than cortex. Podocytes of inner leaf and cytotrabecula in the normal state, prevail over such in a state of destruction.

\section{Discussion}

The analysis of electron microscopic material related to the above-mentioned groups of experimental study showed that the leading place in the development of pathological changes in the tissues of the kidneys under the common modeling of the AP and diabetes have type I diabetes. It should be noted that in the nephrons and tubules of the cortex, the above changes appear to a much greater extent than in the kidney medulla.

According to number of authors, ischemia is one of the most important triggers of programmed cell death (PCD) initiation as a significant pathogenetic factor in the development of infectious and inflammatory processes in the kidneys [8, 12, 16, 17].

It was also established that proximal straight tubule is most prominent in the part of the nephron, which is sensitive to ischemia [12, 13]. In modern studies, this phenomenon is associated with the fact that the membrane of cells of the proximal tubule contains the largest among all segments of the nephron amount of ATP-dependent transport proteins. Ischemia causes a rapid depletion of the ATP pool in these cells, which causes their osmotic swelling, fragmentation of mitochondria, dissociation of the cytoskeleton with subsequent violation of the integrity of the cytoplasmic membrane and cell necrosis $[4,5,6]$.

Contemporary literature data on ultrastructural manifestations of PCD suggest that the most pronounced changes in the Henle loop, the distal tubule and the collection tube are the blockage of the lumen of the tubules by the bodies of epithelial cells that were swollen with flake-like aggregates, cell detritus, and also the aggregation of red blood cells in peritubular blood capillaries $[4,5,13]$.

Someauthors $[4,6]$ have suggested that such obstruction of the nephrons, along with the damage to the tubular cells, is an additional barrier to the restoration of normal hemodynamics in the kidney and affects the course of the apoptotic process.

EM studies that have high informativeness in the study of ultrastructural pathological changes in thetissues of the kidneys appear to be more appropriate in clinical conditions in the study of the pathogenetic features of acute pyelonephritis in conditions of concomitant diabetes mellitus with the aim to further selecting the optimal corrective therapeutic effect and preventing the adverse flow of the infectious and inflammatory process and its transformation into a persistent form. 


\section{Conclusions}

1. In conditions of reproduction of experimental models of acute pyelonephritis and concomitant diabetes mellitus types I and II, the leading role in the development of pathological changes in the tissues of the kidney plays a role diabetes type 1 .

2. The pathological changes in the renal tissue revealed in the experiment have more significant manifestations, namely: in the proximal straight tubule focal local destruction

\section{References}

[1] Dorogoj, A. P. (2007). Life expectancy, potential labor potential losses, and death in diabetes mellitus. International Endocrinology Journal, 3(9), 10-12.

[2] Kuznetsova, O. P., Vorobiev, P. A., \&Yakovlev, S. V. (1997). Urinary tract infections. Russian Medical Journal, 1, 4-13.

[3] Novikov, V. S. (1996). Programmed cell death. S.-Pb.: Science. Retrieved from humbio.ru/humbio/starenie/ 0001d36e.htm

[4] Pak, L. B., Dubikov, A. I., Kabantseva, T. A., Vasilyuk, A. A., \& Grigoryan, O. M. (2013). Apoptosis and kidney pathology. Nephrology, 17(4), 36-43. ISSN 1561-6274.

[5] Popov, S. V., Guseinov, R. G., Gorshkov, A. N., Sivak, K. V., Yablonskiy, P. K., Skryabin, O. N., \& Vinogradova T. I. (2016). Changes in the ultrastructural organization of the kidney under the conditions of experimentally modeled thermal ischemia in surgical intervention. Bulletin of St. Petersburg University, 11(1), 104-119. Retrieved from vestnik.spbu.ru/html16/s11/s11v1/10.

[6] Tomilina, N. A., \& Bikbov, B. T. (2005). Epidemiology of chronic renal failure and new approaches to the classification and evaluation of the severity of chronic progressive kidney disease. Therapeutic archive, 6, 87-89. Retrieved from onco.tnimc.ru/journal/lib-archive/terapevticheskiy-arkhiv/

[7] Vinnichenko, L. N. (1980). Comparative ultrastructure of nephron. L.: Nauka, 136. Retrieved from www.cytspb.rssi.ru/ books/vinnichenko_ru.htm

[8] Becker, F., Van Poppel, H., Hakenberg, O. W., Stief, C., Gill, I., Guazzoni, G., ... Stockle, M. (2009). Assessing the impact of ischaemia time during partial nephrectomy. Eur. Urol., 56, 625 - 635. doi: 10.1016/j. eururo.2009.07.016.

[9] Bhayani, S. B., Rha, K. H., Pinto, P. A., Ong, A. M., Allaf, M. E., Trock, B. J. ... Kavoussi, L. R. (2004). Laparoscopic partial nephrectomy: effect of warm ischemia on serum creatinine. J. Urol., 172(4), 1, 1264-1266. Retrieved from https:// www.ncbi.nlm.nih.gov/pubmed/15371820

[10] Donohoe, J. F., Venkatachalam, M. A., Bernard, D. B. \& Levinsky, N. G. (1978). Tubular leakage and obstruction of organelles, separate mitochondria with homogenization of crista. Elements of interstitial tissue in the state of edema. The structure of the cortical substance is more damaged than the medulla.

3. EM studies have high informative character in the pathological changes and early dynamic processes of apoptosis in kidney tissues under simulation conditions in the experiment of acute pyelonephritis and concomitant diabetes mellitus I and II types.

after renal ischemia: structural-functional correlations. Kidney Int., 13(3), 208-222. https://doi.org/10.1038/ki. 1978.31

[11] Gill, I. S., Colombo, J. R. Jr., Moinzadeh, A., Finelli A., Ukimura O., Tucker K., ... Desai, M. (2006). Laparoscopic partial nephrectomy in solitary kidney. J. Urol., 175(2), 454-458. doil: 10.1016/S0022-5347(05)00150-3

[12] Hansson, J., Hultenby, K., Cramnert, C., Ponten, F., Jansson, H., Lindgren, D. ... Johansson, M. E. (2014). Evidence for a morphologically distinct and functionally robust cell type in the proximal tubules of human kidney. Hum. Pathol., 45, 382-393. doi: 10.1016/j.humpath.2013.10.003

[13] Humphreys, B. D., Czerniak, S., Dirocco, D. P., Hasnain, W., Cheema, R., \& Bonventre, J. V. (2011). Repair of injured proximal tubule does notinvolve specialized progenitors. Proc. Natl. Acad. Sci. USA, 108(22), 9226-9231. doi: 10.1073/ pnas. 1100629108.

[14] Porpiglia, F., Renard, J., Billia, M., Musso, F., Volpe, A, Burruni, R. ... Scarpa, R. M. (2007). Is renal warm ischemia over 30 minutes during laparoscopic partial nephrectomy possible? One-year results of a prospectivestudy. Eur. Urol., 52(4), 1170-1178. doi: 10.1016/j.eururo.2007.04.024

[15] Reynoldes, E. S. (1963). The use of lead citrate at higt pH an electronopaque stain in electron microscopy. J. of Cell Biology, 17, 208-212. Retrieved from https:// www.ncbi.nlm.nih.gov/pubmed/13986422

[16] Thompson, R. H., Lane, B. R., Lohse, C. M., Leibovich, B. C., Fergany, A., Frank, I. ... Campbell, S. C. (2010). Every minute counts when the renal hilum is clamped during partial nephrectomy. Eur. Urol., 2010, 58(3), 340-345. doi: 10.1016/ j.eururo.2010.05.047

[17] Tirapelli, L. F., Barione, D. F., Trazzi, B. F. M., Tirapelli, D. P. C., Novas, P. C., Silva, C. S. ... Martins, A. C. P. (2009). Comparison of two models for evaluation histopathology of experimental renal ischemia. Transplant. Proc., 41, 4083-4087.

[18] Verlander, J. W. (1998). Normal ultrastructure of the kidney and lower urinary tract. Toxicol. Pathol., 26(1), 1-17. doi: $10.1177 / 019262339802600101$

\section{ЕЛЕКТРОННО-МІКРОСКОПІЧНА ДІАГНОСТИКА ПРОЦЕСІВ АПОПТОЗА ЗА УМОВ МОДЕЛЮВАННЯ В ЕКСПЕРИМЕНТІ ГОСТРОГО ПІЄЛОНЕФРИТУ ТА СУПУТНЬОГО ЦУКРОВОГО ДІАБЕТУ І ТА ІІ ТИПІВ Борисов С.О. Костев Ф.І. Борисов О.В. Молчанюк Н.И.}

Як свідчать літературні дані, в умовах порушення балансу про- та протизапальних факторів розвиток інфекційно-запального процесу набуває тенденції до прогресування і більш важкого перебігу з подальшою трансформацією у хронічне запалення 3 відповідними морфофункціональними наслідками. За таких критичних умов вирішальнузахисну роль, імовірно, відіграє апоптоз, котрий здатний усунути надмірне скупчення агресивних ефекторів запалення, їх ефективно елімінувати, що в подальшому попередить імовірну трансформацію у персистуючу форму. Метою роботи стало вивчення особливостей ранніх динамічних процесів апоптоза в тканинах нирок за умов моделювання в експерименті гострого пієлонефриту та супутнього цукрового діабету I та II типів. Робота виконана на 300 дорослих щурах лінії Вістар, що були розподілені на 4 групи. Фрагменти нирок тварин вивчали і фотографували в електронному мікроскопі ПЕМ-100-01. Результати показали, що після моделювання у тварин пієлонефриту в нефронах не було значних ультраструктурних змін. Структура подоцитів зовнішнього листка практично була аналогічною структурі подоцитів контрольного матеріалу, а в деяких клітинах спостерігались ознаки активації ї 
метаболічної активності. У структурі подоцитів внутрішнього листка капсули встановлені дистрофічні зміни внутрішньої мембрани частини мітохондрій. У мозковій речовині нирки структура клубочка була більш збереженою, ніж у кірковій. Патологічні зміни подоцитів проксимальних та дистальних канальців, а також інтерстиціальної тканини більш виражені, ніж ниркового клубочка. За умов моделювання співдружньої моделі пієлонефриту і діабету I типу відбуваються більш виражені морфологічні зміни: деструктивно значно змінюються ендотеліальні клітини капілярів клубочка, відбувається гомогенізація структури базальної мембрани та значно розростається мезангіальна тканина. У нефронах і канальцях кіркової речовини зміни проявляються у значно більшій мірі, ніж у мозковій речовині нирки. При вивченні в клінічних умовах патогенетичних особливостей гострого пієлонефриту за умов супутнього цукрового діабету доцільним є проведення електронномікроскопічних досліджень з метою обрання оптимального коригуючого лікувального впливу та запобігання несприятливого перебігуінфекційно-запальногопроцесу тайого трансформації уперсистуючу форму. ЕМ-дослідження євисоко інформативним при дослідженні патологічних змін та ранніх динамічних процесів апоптоза в тканинах нирки при моделюванні гострого пієлонефриту та супутнього цукрового діабету I та II типів в умовах експерименту.

Ключові слова: моделювання, патогенез, пієлонефрит, цукровий діабет, електронна мікроскопія, кіркова та мозкова речовина, апоптоз.

\section{ЕЛЕКТРОННО-МИКРОСКОПИЧЕСКАЯ ДИАГНОСТИКА ПРОЦЕССОВ АПОПТОЗА В УСЛОВИЯХ МОДЕЛИРОВАНИЯ В ЭКСПЕРИМЕНТЕ ОСТРОГО ПИЕЛОНЕФРИТА И СОПУТСТВУЮЩЕГО САХАРНОГО ДИАБЕТА I И І| ТИПОВ \\ Борисов С.А., Костев Ф.И., Борисов А.В. Молчанюк Н.И.}

Согласно литературным данным, в условиях нарушения баланса про- и противовоспалительных факторов развитие инфекционно-воспалительного процесса приобретает тенденцию к прогрессированию и более тяжелого течения $c$ дальнейшей трансформацией в хроническое воспаление с соостветствующими морфофункциональными последствиями. В таких критических условиях решающую защитную роль, вероятно, сыграет апоптоз, который способен убрать чрезмерную скупченность агрессивных эффекторов воспаления, их эффективно элиминировать, что предупредит в дальнейшем возможную трансформацию в персистирующую форму. Целью работы стало изучение особенностей ранних динамических процессов апоптоза в тканях почек в условиях моделирования в эксперименте острого пиелонефрита и сопутствующего сахарного диабета I и II типов. Работа выполнена на 300 взрослых крысах линии Вистар, которые были распределены на 4 группы. Фрагменты почек животных изучали и фотографировали в электронном микроскопе ПЭМ-100-01. Результаты показали, что после моделирования у животных пиелонефрита в нефронах не было значительных ультраструктурных изменений. Структура подоцитов внешнего листа практически была аналогичной структуре подоцитов контрольного материала, а в некоторых клетках наблюдались признаки активации их метаболической активности. В структуре подоцитов внутреннего листка капсулы установлены дистрофические изменения внутренней мембраны части митохондрий. $B$ мозговом веществе почки структура клубочка была более сохранной, чем в корковом. Патологические изменения подоцитов проксимальных и дистальных канальцев, а также интерстициальной ткани более выражены, чем почечных клубочков. $B$ условиях моделирования содружественной модели пиелонефрита и диабета I типа происходят более выраженные морфологические изменения: деструктивно значительно изменяются эндотелиальные клетки капилляров клубочка, происходит гомогенизация структуры базальной мембраны и значительно разрастается мезангиальная ткань. В нефронах и канальцах коры изменения проявляются в значительно большей степени, чем в мозговом веществе почки. При изучении в клинических условиях патогенетических особенностей острого пиелонефрита в условиях сопутствующего сахарного диабета целесообразным является проведение электронно-микроскопических исследований с целью избрания оптимального корректирующего лечебного воздействия и предотвращения неблагоприятного течения инфекционновоспалительного процесса и его трансформации в персистирующую форму. Электронно-микроскопическое исследование является высоко информативным при исследовании патологических изменений и ранних динамических процессов апоптоза в тканях почки при моделировании острого пиелонефрита и сопутствующего сахарного диабета I и /I типов в условиях эксперимента.

Ключевые слова: моделирование, патогенез, пиелонефрит, сахарный диабет, электронная микроскопия, корковое и мозговое вещество, апоптоз. 